\title{
A SINGULAR CREMATOGASTER FROM GUATEMALA
}

\author{
By William MORTON WheELER
}

Among a number of ants which I collected during the spring of 1935 in Guatemala one of the Crematogasters is so unusual that it merits special description. Two colonies of these insects were found while I was collecting with Dr. Marston Bates on March 19 (which happened to be my seventieth birthday) along the northern shore of the exquisitely beautiful Lake Atitlan. Each colony was nesting in the soil under a stone, one in an open sandy spot a quarter of a mile south of the hotel at Tsanjuyo, the other in a grassy meadow about a mile farther on, near the village of Panajachel. The approximately equal populations of both these colonies comprised males, females, workers and brood. The extraordinary appearance of the males, which were small, wingless, slow-moving creatures with conspicuous white thoraces and clung huddled together on the lower surface of the stone when they were not being carried about by the workers, led me to collect as many specimens as possible of the adults and brood of all the castes. It was the very height of the dry season, and further search in the two localities revealed no other colonies of this ant or indeed of other species, except a few colonies of the fire-ant (Solenopsis geminata Fabr.) and of certain common forms of Pseudomyrma and Camponotus, which were nesting in the dead branches of the trees and shrubs.

Comparison of specimens from the two Crematogaster colonies with other Neotropical species of the genus shows that the workers are so similar to those of C. (Orthocrema) sumichrasti Mayr that, apart from coloration, no important differences can be detected. The worker and female of the typical sumichrasti from Mexico are yellow, whereas the corresponding castes of the Atitlan form are dark brown or 
black. The male of the latter also differs from the male sumichrasti in having the thorax and pedicel ivory white, instead of yellow and the head and gaster more deeply infuscated, and both the male and the female are completely apterous, even in the pupal stage, instead of possessing welldeveloped wings like sumichrasti. Many years ago (1884), Forel described the worker and female (presumably winged or deälated) of a form of sumichrasti collected by Stoll at Antigua, Guatemala, as subsp. surdior. Two worker cotypes of this ant in my collection show that the body is pale reddish castaneous and hence intermediate in color between the typical sumichrasti and the form from Lake Atitlan. Yet the aptery of both sexual castes of the latter, a condition unique among all known Formicidæ, suggests two problems, one involving the interpretation of the constitution of the colony as a whole, the other purely taxonomic. In other words, we are led to inquire whether the personnel of each of the colonies which I collected consists of a single independent, or of two different'species, living in host and parasite relation. Either a positive or a negative answer to this question necessarily implies the further question as to the taxonomic status of the Atitlan specimens.

That we are dealing with only a single form in each of the two colonies is indicated by the following considerations:-

(1) Apart from coloration, which can have only varietal significance, and the aptery of the two sexual castes, which to the taxonomist is a more important character, there is very little to distinguish the Atitlan form from sumichrasti.

(2) The darker color of the worker and female and the aptery of both sexual castes might be interpreted as mutations that have survived in a peculiar xerothermal environment. This is suggested by the fact that the colonies were nesting in the ground in exposed situations, whereas all or nearly all the other known species of the subgenus Orthocrema are forest ants which nest in plant-cavities. This is true even of the typical sumichrasti and its subsp. surdior. The type colony of the latter, according to Forel, was found attending aphids under the leaf-sheaths of a banana plant, and recently Dr. Skwarra (1934, p. 120) has recorded the 
following sites in which she observed the typical sumichrasti nesting in various Mexican localities: in the trunk of a tree, in the stem-cavities of Cecropia mexicana, under the leaf-bases of bananas, in the stems of the Melastomaceous plant Conostegia xalapensis, in the pseudobulbs of the orchid Schomburgkia tibicinis, and most frequently between the overlapping leaves of Bromeliads, namely, Aechmia mexicana and the following species of Tillandsia: Balbisiana, dasyliriifolia, pruinosa, streptophylla, Valenzuelana and viridifolia. Forel (1908) records the typical sumichrasti as having been taken by Biolley at San Jose, Costa Rica $(1160 \mathrm{~m}$.) in decayed wood. The very different habitat of the Atitlan colonies might account for the deeper pigmentation of all three castes and, perhaps, for the aptery of the males and females. The physiological causes of aptery in insects, however, are apparently obscure and very diverse. To contend that the "genes for winged" have completely dropped out of the germ-cells of these ants would be merely, if a mixed metaphor may be permitted, to make a "Ruhekissen" out of a photograph of the problem.

It is more probable that each of the Atitlan colonies is a mixture of two species, one of which, comprising the apterous males and females, is an undescribed workerless parasite, the other an undescribed subspecies of $C$. sumichrasti, represented only by the workers and functioning as the host.

(1) In the field the depauperate appearance of the colonies and the peculiar males at once suggested this interpretation, because Crematogaster colonies containing young sexual individuals are, as a rule, very populous. According to Dr. Skwarra's observations, those of the typical sumichrasti even contain several mother queens, frequently as many as 16 to 20 , and are probably of pleometrotic origin. She mentions one colony which comprised 31 deälated females and 962 workers, and another 164 deälated females and about 1200 workers. These are by no means unusually large colonies compared with those of many other species of Crematogaster. As shown in the following table, however, the combined populations of the two Atitlan colonies, including their brood, are very meager: 


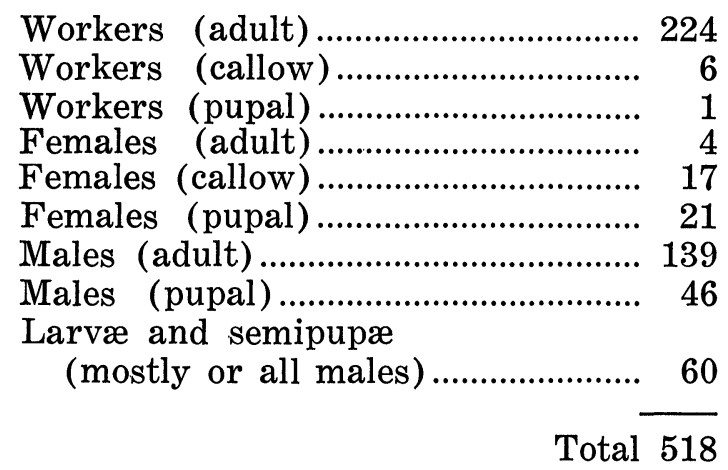

Since the two colonies were of about the same size the workers in each averaged about 115 and were therefore only a ninth or a twelfth as numerous as in the two welldeveloped sumichrasti colonies observed by Dr. Skwarra.

(2) Closer scrutiny of the preceding table yields even firmer support for the contention that the wingless males and females are parasites, because in genera of workerless parasites, of which Wheeleriella and Anergates may be regarded as typical, the host queen is assassinated either by her own workers or by the intrusive queen and the brood of the host species is therefore lacking. It will be seen from the table that there were only one pupal and six callow workers in the two colonies. Of the 60 larvæ and semipupæ mentioned at the end of the list, the semipupæ, which numbered 36, are undoubtedly, and the 24 larvæ, which are too small to exhibit sexual characters, are very probably all or mostly males. Of the four adult females, three were taken from the colony near Panajachel, and one from the colony near Tsanjuyo. The latter, in all probability, is the original mother of all the larval, callow and adult sexual forms of that colony, but whether the other colony contained three mother queens or whether two of them were her mature daughters cannot be determined, owing to their equally deep pigmentation and complete aptery. Dr. Skwarra's observations on the pronounced pleometrotic proclivities of the typical sumichrasti suggest that all three queens may have been the mothers of the males, females and brood of the colony near Panajachel. 
(3) The foregoing interpretation is supported also by the putative parasitism of several other species of Crematogaster. As early as 1910 I called attention to the species of the Ethiopian, Malagasy and Indomalayan subgenus Oxygyne, in which the females have peculiar falcate mandibles, as probably being temporary social parasites in the nests of other species of Crematogaster. ${ }^{1}$ This statement would seem to apply also to two other Ethiopian subgenera, Atopogyne and Nematocrema. The females of the former have large rectangular heads and robust subfalcate mandibles, while the females of Nematocrema resemble those of Oxygyne. Crematogaster acuta Fabr., a rather common Neotropical species, which Emery regarded as the type of the subgenus Crematogaster sens. str. (Santschi's subgenus Eucrema), has small females, with small gaster like that of the worizer, and with smooth integument quite unlike that of the worker, and is therefore, in all probability, a temporary social parasite. More suggestive in this connection are two species (kennedyi and creightoni) of the subgenus Acrocelia which I described recently $(1930,1933)$ from nests of our common North American $C$. $(A$.) lineolata Say as workerless parasites. Except in possessing well-developed wings they are strictly comparable to the females and males of the Atitlan colonies. Obviously in all three cases we are dealing with parasites that are phylogenetically descended from their respective host species and have completely lost their worker caste. ${ }^{2}$ This derivation seems to be more recent in the North American Acrocolias than in the Atitlan form since in the latter both castes have lost their wings. The series of other known workerless parasites suggests that aptery develops sooner in the male than in the

\footnotetext{
1 Emery (1897) described and figured an old mother queen of Oxygyne ranavalonoe Forel of Madagascar as strongly physogastric like the old mother queens of Anergates atratulus.

${ }^{2}$ For an account of the considerable number of Aculeate parasites that may be derived phylogenetically from their host genera or species see my paper of 1919. The parasitic Vespids, Vespula austriaca, omissa and adulterina and the parasitic bumble-bees of the genus Psithyrus are strictly comparable with the winged workerless parasites among ants belonging to the genera Wheeleriella, Epœcus, Labauchena, Pseudoatta, Sympheidole, Epipheidole, Gallardomyrma, etc.
} 
female. Thus in Bruchomyrma acutidens Santschi, an Argentinian parasite of Pheidole nitidula strobeli Santschi, the female has large though veinless wings but the wings of the male are considerably reduced; in the Congolese Anergatides kohli Wasmann, a parasite of Pheidole megacephala melancholica Santschi, the wings in the female are like those of Bruchomyrma, but the male is subapterous, and in the well-known European Anergates atratulus, which parasitizes Tetramorium cæspitum, the female has well-developed, veined wings, but the male is completely apterous. The final stage is represented by the Atitlan Crematogaster, in which, as I have repeatedly stated, both sexual castes are apterous. Nevertheless, the loss of the wings seems to have been so recent that it has affected neither the volume and structure of the thorax nor the volume of the wing-musculature. Mating in this form must, of course, occur in the nest and between brothers and sisters (adelphogamy), as in Anergates, but there can be no dissemination flight as in that species. The females, as soon as they are mature and have been fecunded, very probably wander away from the nest singly, and, in order to insure the rearing of their brood, enter and secure adoption in weak colonies of the host species.

We have still to consider the taxonomic status of the Crematogasters discussed in the preceding paragraphs. The complete aptery of the sexual phases, whether we regard them as representing an independent species or as cospecific with the workers, is a character of sufficient importance to justify the erection of a new subgenus. Since I have interpreted the sexual forms as workerless parasites I propose the name Apterocrema subgen. nov. for the males and females and describe them below as a new species, atitlan$i c a$. The workers, however, would belong to a new subspecies of sumichrasti, for which I propose the name maja, allied to Forel's subsp. surdior and therefore belonging to the subgenus Orthocrema. Should the future investigator succeed in demonstrating that the sexual castes and workers are cospecific, he might be willing to retain my subgeneric name, but maja would, of course, become a synonym of atitlanica. 

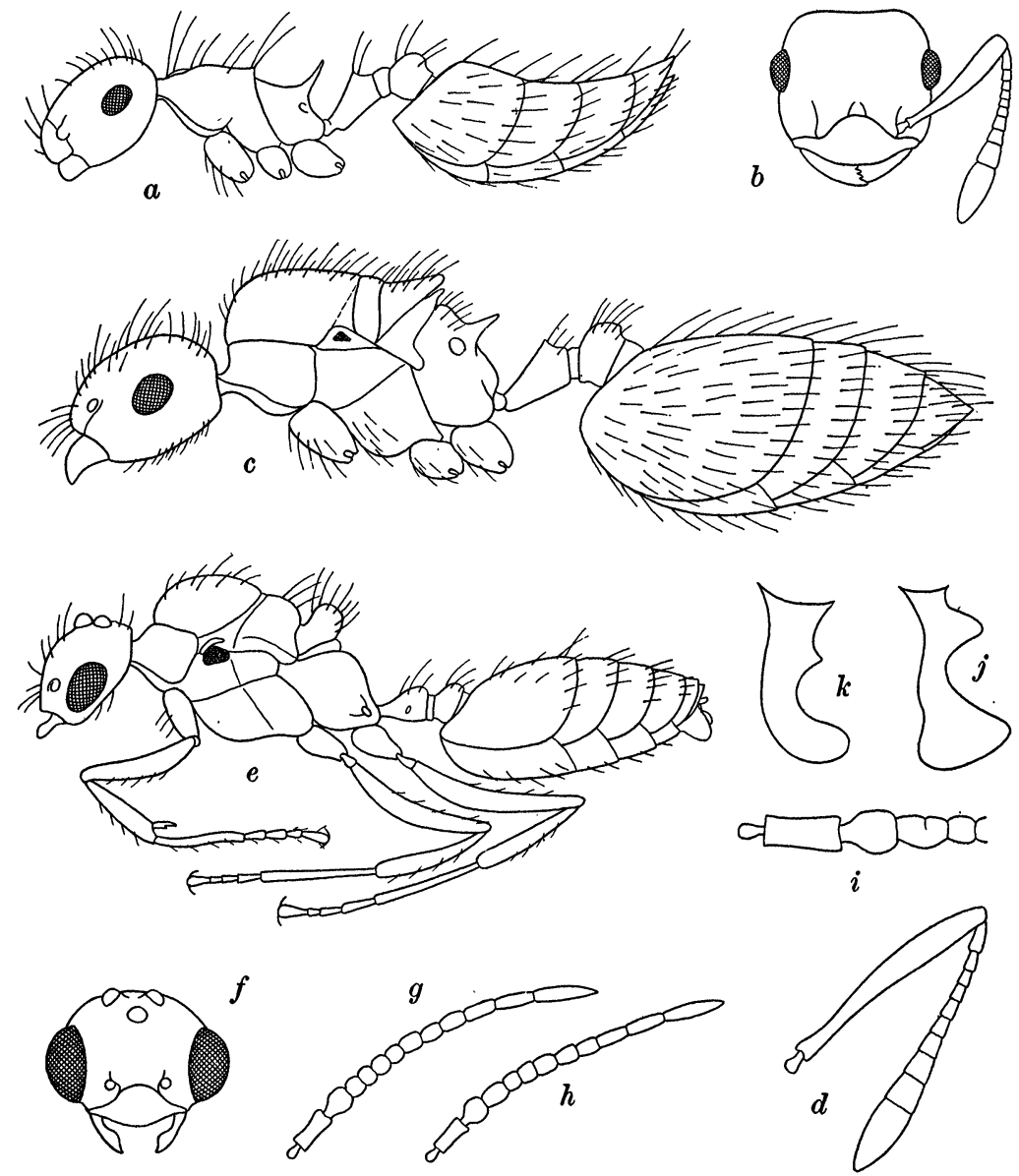

Fig. 1. a, Crematogaster (Orthocrema) sumichrasti maya subsp. nov. Worker in profile; $b$, head of same, dorsal view; $c, C$. (Apterocrema) atitlanica sp. nov. female in profile; $d$, antenna of same; $e$, male in profile; $f$, head of same, dorsal view; $g, 12$-jointed left and $h$, 11-jointed right antenna of same male specimen; $i$, four basal joints of another male specimen more enlarged, showing partial division of third joint; $j$, volsella of male atitlanica, $k$, volsella of male sumichrast $i$ (typical). 
Crematogaster (Apterocrema) atitlanica sp. nov.

Female. Length: $4.3-4.5 \mathrm{~mm}$.

Very similar to the female of sumichrasti but differing in the following characters: Head slightly narrower in proportion to its length; eyes distinctly larger, very nearly as long as their distance from the anterior corners of the head; clypeus more flattened in the middle anteriorly, between the carinæ, which are sharper than in sumichrasti. Wings absent, but tegulæ of fore wings persisting as minute, elongate scales articulated to a small, heavily sclerotized and, in the pupa and callow, black area. Epinotal spines longer and usually more slender and more acute than in sumichrasti. Petiole and postpetiole narrower and less robust.

In sculpture and pilosity very similar to sumichrasti, but the rugosity of the sides of the epinotum is sharper, as is also the punctuation of the petiole and postpetiole, the latter also longitudinally striolate. The sparse golden pilosity is as in sumichrasti, very long and conspicuous on the gaster and dorsum of the pedicel, thorax and head, shorter but coarse on the scapes, gula and legs.

Black or very dark brown; thorax and pedicel in less mature specimens reddish brown, especially along the sutures; legs and antennæ dark brown; mandibles, tips of scapes, clubs of funiculi, coxæ, trochanters, tarsi and posterior borders of gastric segments brownish yellow.

Male. Length 2.5.-2.8 $\mathrm{mm}$.

Structurally very similar to the male sumichrasti. Integument thin and collapsible. Mandibles and antennæ as in sumichrasti, the former small and acute but edentate, the latter usually 11-jointed, with the third joint (second funicular) entire or partially divided, sometimes 12-jointed, when the division is complete, more rarely 10 -jointed. The three terminal joints are apparently stouter than in sumichrasti. Thorax wingless; with vestiges of tegulæ as in the female. Volsella of genitalia much more expanded at the tip than in the male sumichrasti.

Sculpture and pilosity as in that form. Ivory white; head, except the clypeus, mandibles and mouthparts, dark brown, especially posteriorly; tibiæ and gaster paler brown, segments of the latter dull yellowish at the base and along 
their posterior borders. Thorax with a conspicuous small black spot on each side at the tegular insertions as in the immature female and also as in the male sumichrasti.

Crematogaster (Orthocrema) sumichrasti maya subsp. nov.

Worker. Length 3-3.3 $\mathrm{mm}$.

Very similar to the typical sumichrasti but differing as follows: Clypeal carinæ more pronounced, antennal scapes extending only $1 / 5$ their length beyond the posterior border of the head (in sumichrasti 1/4); lateral marginations of mesonotum and denticles at its posterior end more pronounced as in the subsp. surdior; epinotal spines longer and more distinctly recurved; petiole more narrowed anteriorly.

Sculpture as in sumichrasti but the mandibles more coarsely striated and more opaque and the pronotum longitudinally rugulose.

Pilosity yellow as in sumichrasti and very long, especially on the thorax and gaster.

Black or brown black, much darker than the subsp. surdior; mandibles, club of antennæ, trochanters and tarsi brownish yellow.

\section{Literature Cited}

1897. Emery, C. Glanures Myrmécologiques. Bull. Soc. Ent. France, pp. 13, 14, fig.

1884. Forel, A. Etudes Myrmécologiques en 1884. Bull. Soc. Vaud. Sc. Nat. 20 , p. 60.

1908. Forel, $A$. Fourmis de Costa Rica recoltées par M. Paul Biolley. Bull. Soc. Vaud. Sic. Nat. (5) 44, p. 46.

1934. Skwarra, $E$. Oekologische Studien über Ameisen und Ameisenpflanzen in Mexico. R. Leopold, Königsberg, p. 120.

1910. Wheeler, W. M. Ants, their Structure, Development and Behavior. Columbia Univ. Press. pp. 448, 449.

1919. Wheeler, $W . M$. The Parasitic Aculeata, a Study in Evolution. Proc. Amer. Philos. Soc. 58, pp. 1-40.

1930. Wheeler, $W . M$. A New Parasitic Crematogaster from Indiana. Psyche 37, pp. 55-60.

1933. Wheeler, $W . M$. A Second Parasitic Crematogaster. Psyche 40, pp. 83-86. 

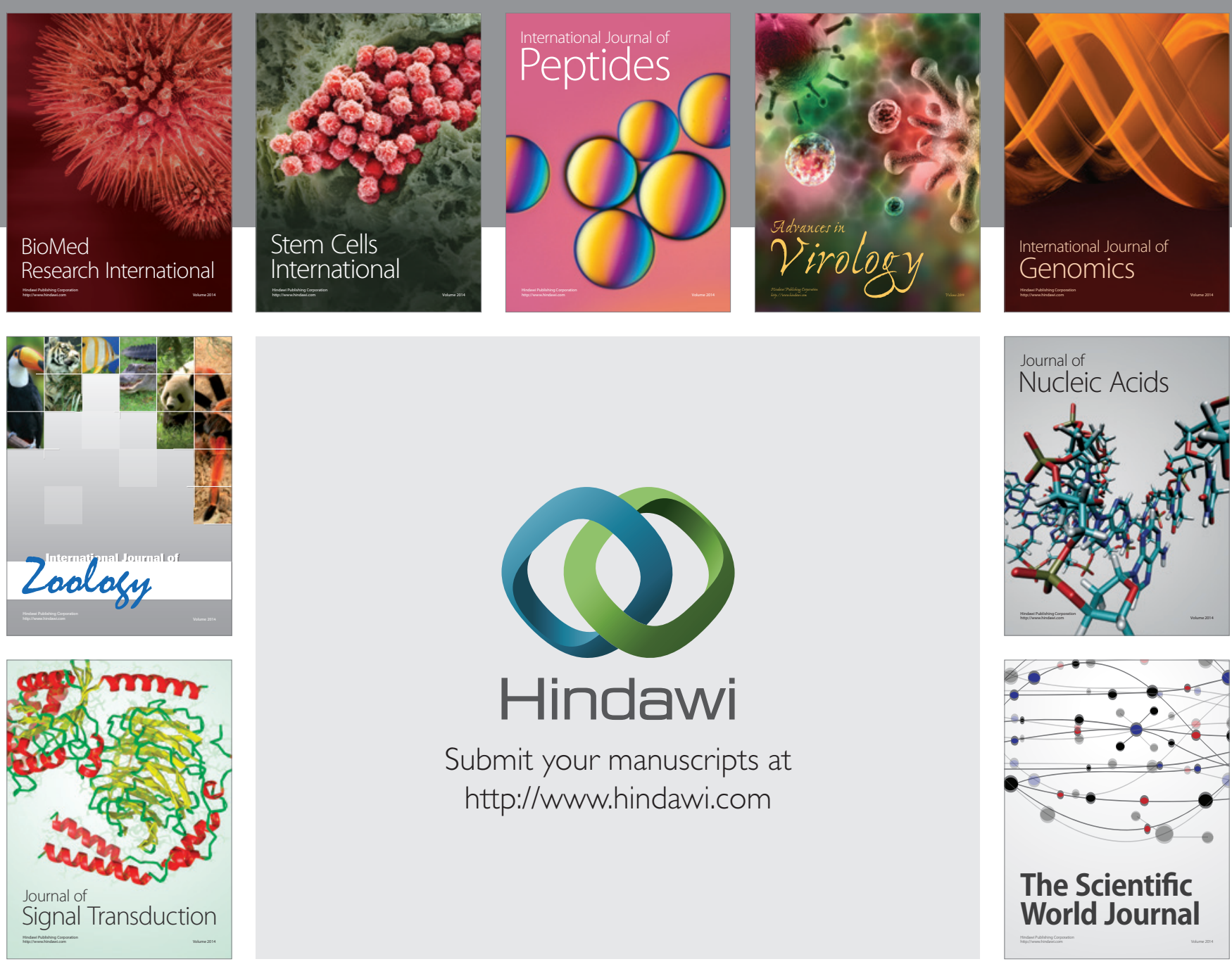

Submit your manuscripts at

http://www.hindawi.com
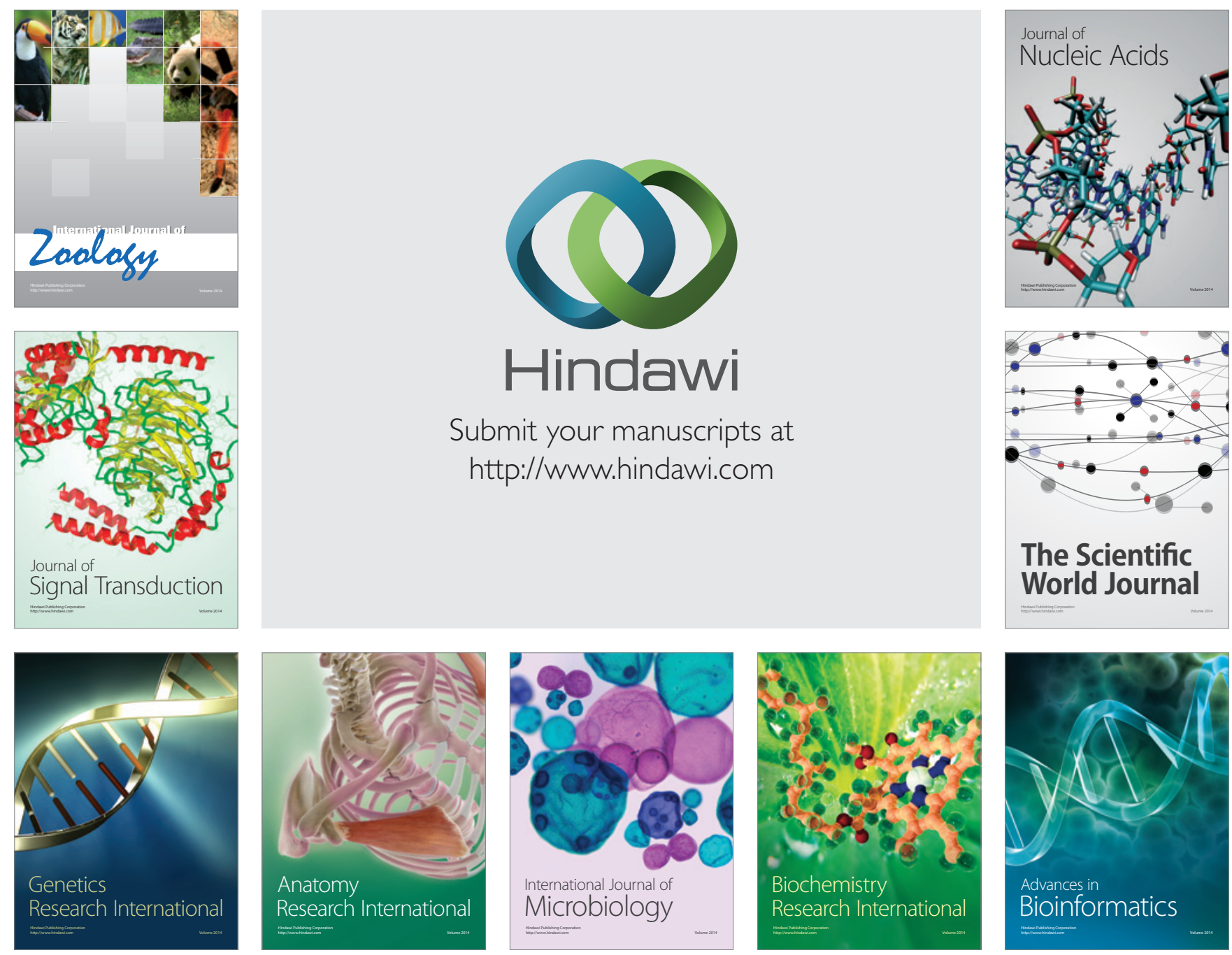

The Scientific World Journal
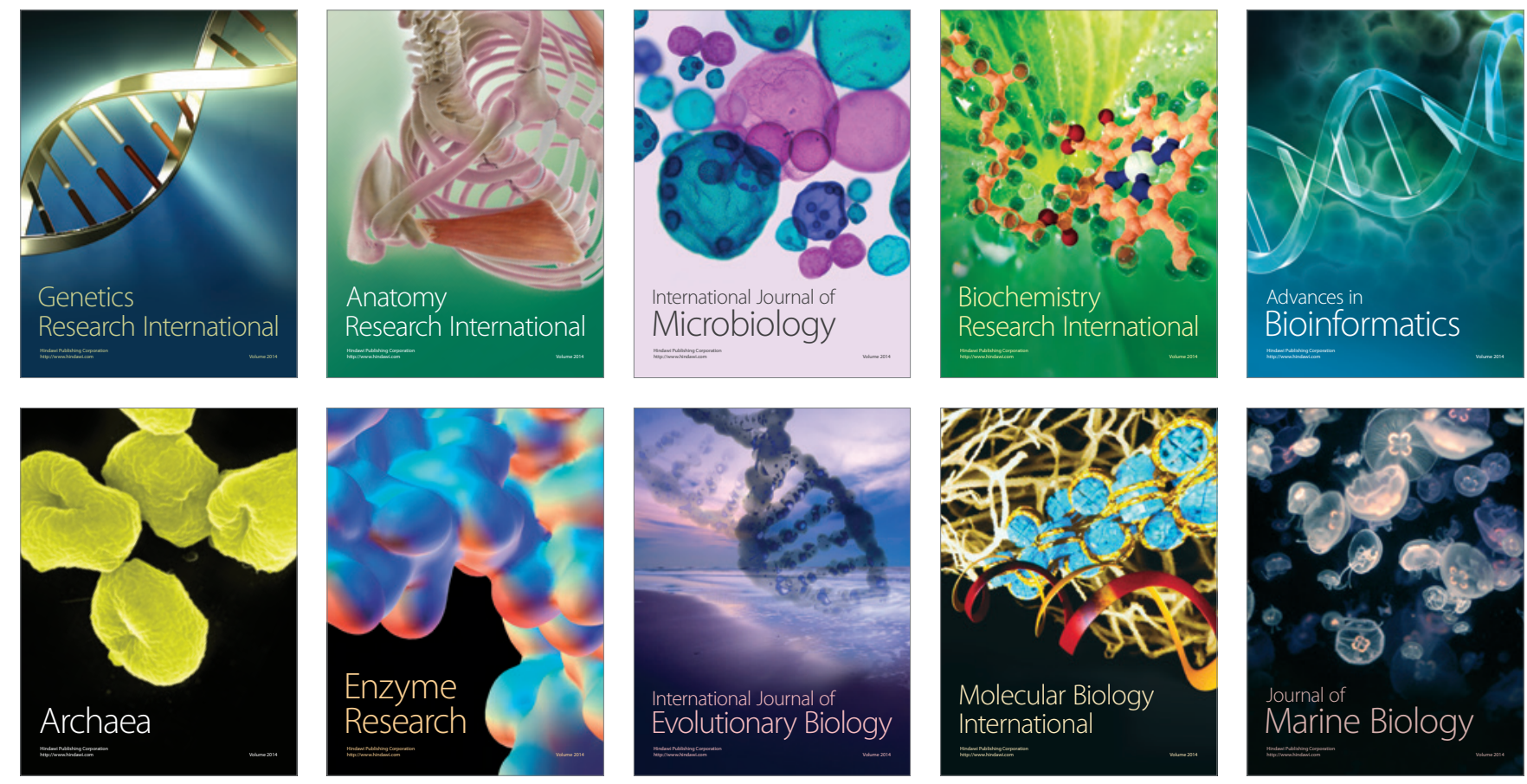